\title{
Notification of intrafamily violence against elderly women in the city of São Paulo
}

Ana Paula dos Santos Guimarães

Carlos Górios $^{2}$

Cintia Leci Rodrigues ${ }^{1}$ Jane de Eston Armond?

\section{Abstract}

Objective: the aim of the present study was to characterize the population of elderly women who have suffered sexual and physical violence and describe the characteristics of this aggression. Method: a cross-sectional study was carried out using secondary data from the Violence and Accident Surveillance Information System, which registers reports of physical and sexual violence against the female population aged 60 and older. Results: in 2013289 acts of physical violence against elderly women in the city of São Paulo were recorded, and sexual violence was reported in ten cases. Conclusion: physical and sexual violence occurred mainly in the family environment, with the majority of aggressors male and a family member or known to the victim. In their direct and daily dealings with elderly health service users at all levels of complexity, doctors should know how to investigate and identify cases of violence, properly approach patients, act in coordination with other professionals and apply interventions that are effective for each case.

Keywords: Elder Abuse. Violence Against Women. Ethics.

\footnotetext{
Universidade de Santo Amaro, Curso de Medicina, Departamento de Medicina e Comunidade. São Paulo, SP, Brasil.

2 Centro Universitário São Camilo, Curso de Medicina, Departamento de Ortopedia e Traumatologia. São Paulo, SP, Brasil.
} 


\section{INTRODUCTION}

Intrafamily violence encompasses relationships of abuse practiced in a private family context against any of its members. Elderly persons are potential victims of such violence, as they are often dependent on family members in various areas, including health care, social relations, financial matters, or even simple family coexistence ${ }^{1-3}$.

Violence against the elderly population has consequences for physical and mental health and has become a public health problem, due to its prevalence and the severity of its consequences, which include physical, moral and psycho-emotional trauma. Such harm can lead to disability, dependence and even death ${ }^{4}$.

Violence is closely related to the aging-illness process. According to Silva and Dias ${ }^{5}$, cultural issues can also contribute to violence, especially in the domestic environment, where the elderly are often devalued, seen as useless and marginalized ${ }^{5,6}$.

Studies on family violence have gradually sought to understand situations of violence against the elderly. This increased interest is the result of the growth in the number of elderly people and of the work of national and international surveys that have identified the family as the main context of violence against this age group ${ }^{6,7}$.-

Despite the importance of the topic, publications on violence and abuse of the elderly in Brazil are still incipient ${ }^{8}$. The theme of violence against the elderly needs to be more widely studied and the participation of several sectors of society in preventive actions encouraged ${ }^{9}$.

The lack of information about both aggressors and the abused is problematic and is largely caused by the fact that the elderly often fail to report the abuses and aggressions suffered, due to embarrassment and fear of repression by their caregivers, who are themselves often the aggressors. Explaining intrafamily violence against the elderly within or outside the home environment requires that basic health care provides a system that allows the identification of such incidents and proposes actions that address the problem ${ }^{10}$.
The use of data collected by Brazilian information systems through analysis of the health situation and the impact of interventions has increased in recent years ${ }^{11}$. The implementation of the Violence and Accident Surveillance Information System (SIVVA) in the municipal health network of the city of São Paulo allows the production of information for the diagnosis, planning, monitoring and evaluation of actions to combat violence and accidents ${ }^{12}$.

The projected elderly population of the city of São Paulo in 2013 was 1,470,719 inhabitants, with women corresponding to $59.8 \%$ of this group ${ }^{13}$. In the same year, the hospital information system reported spending $\mathrm{R} \$ 30,058,110.88$ (Brazilian real) on external causes in the elderly ${ }^{14}$.

Based on the scenario described, it is believed that providing information on the characteristics of violence against elderly women may assist in creating strategies to tackle the problem within health services ${ }^{15}$.

The effects of violence are clearly perceived within health services, either because of the costs they involve or by the complexity of the care they require. In this sense, this sector has an important role in coping with family violence. However, professionals in this area tend to underestimate the importance of the phenomenon, focusing on physical injuries and rarely attempting to prevent or diagnose the origin of injuries ${ }^{16}$.

The Code of Medical Ethics does not explicitly describe the term "domestic violence". However, some articles refer to the obligation of the medical professional to care for health, dignity and human integrity $^{16}$. In 2003, Law 10,741, known as the Statute of the Elderly, came into force, providing guarantees to protect the elderly ${ }^{17}$.

Elderly persons or indeed any other citizens have the inalienable right to protection against any type of physical aggression, including through the support of the authorities, if they are mistreated or threatened, even by their families. Articles 19 and 57 of the Statute clearly state the obligation of health professionals, as well as doctors and institutions, to report cases of abuse of which they are aware. The complaint can be made to the Council of the Elderly 
(municipal, state or federal), the Public Prosecutor's Office and Police Stations ${ }^{17}$.

Medical professionals have a duty to notify cases of domestic violence that they discover, and may even be required to respond legally and ethically in the case of omission. Although the Code of Ethics or "intrafamily violence", it clearly establishes the duty of a medical professional to care for the health and dignity of his or her patients ${ }^{16,17}$. In view of the above, the present study aimed to characterize the population of elderly women who have suffered sexual and physical violence, and to describe the characteristics of the aggression that occurred and the care provided in the city of São Paulo in 2013 based on the Violence and Accident Surveillance Information System (SIVVA).

\section{METHODS}

A cross-sectional, quantitative, descriptive, retrospective study was carried out.

A survey was performed of data from the Violence and Accident Surveillance Information System (SIVVA) of the Municipal Health Department of the city of São Paulo, which registers reports of physical and sexual violence against the female population aged 60 and over by means of a notification form for suspected or confirmed cases ${ }^{18}$.

The inclusion criteria for the study were records of violence (physical and sexual) in women aged 60 years or older. Other variables collected in the database were: age (in years), type of violence (physical and sexual), frequency of violence, degree of kinship of the aggressor in relation to the victim, type of instrument of aggression, diagnosis of injury, result of case (referral for services, hospital discharge),

location of violence (street, home, long-term care facility), disability (physical, mental, visual).

The definitions of physical and sexual violence adopted in this study, according to the Ministry of Health were ${ }^{19}$.

- Physical Violence: occurs when a person, who is in a relationship of power with another, causes or attempts to cause non-accidental harm, through the use of physical force or some type of weapon that may or may not cause external or internal injuries or both. According to more recent concepts, repeated, non-severe punishment is also considered physical violence.

- Sexual Violence: any action in which a person in a relationship of power and through physical force, coercion or psychological intimidation, forces another into the sexual act against their will, or exposes them to sexual interactions that propitiate their victimization, from which the aggressor seeks to obtain gratification,

After data collection, all the data were processed and tabulated. The analysis of these data was based on descriptive statistics, on the basis of which the absolute and relative frequencies were calculated.

The research project did not require approval from the Research Ethics Committee of the University, as it uses a public domain database, according to Resolution 466/12 of the National Health Council (CNS).

\section{RESULTS}

During the year of 2013, 289 cases of physical violence were reported against elderly women in the city of São Paulo. In the same period ten cases of sexual violence were reported (Table 1). 
Table 1. Elderly female victims of physical and sexual violence by age group. São Paulo, 2013.

\begin{tabular}{lll}
\hline Age Group (in years) & $\mathrm{n}$ & $(\%)$ \\
\hline 60 to 64 & 97 & 32.4 \\
65 to 69 & 74 & 24.7 \\
70 to 74 & 56 & 18.7 \\
75 to 79 & 39 & 13.0 \\
80 to 84 & 20 & 6.7 \\
85 to 89 & 08 & 2.7 \\
$\geq 90$ & 05 & 1.7 \\
\hline Total & 299 & 100.0 \\
\hline
\end{tabular}

In relation to physical aggression against elderly women, $73.7 \%$ of aggressors were family members or known to the victim and $41.7 \%$ were male. A total of $62.3 \%$ of incidences of violence occurred within the residences of the elderly women. A total of $76.5 \%$ of the cases involved the use of physical strength and $4.5 \%$ involved a blunt object. In terms of the frequency of aggression, $28.4 \%$ of the elderly victims of physical aggression said it was not the first time they had suffered physical abuse.

The main injury diagnoses were: $9.7 \%$ superficial head trauma and 3.8\% physical injuries, while data on this subject was not provided in $18.0 \%$ of cases.

In cases of sexual violence committed against elderly women, $70.0 \%$ of aggressors were family members and 30\% were unknown persons (thieves and muggers). A total of $50 \%$ of aggressors were male while $50 \%$ of cases did not provide this data. With regard to the location of the aggression, $40.0 \%$ of cases occurred in the victim's home while the other cases did not provide this data. The instrument of aggression was the use of physical strength (40.0\%). In terms of the frequency of aggression, $80.0 \%$ of cases did not provide this data, $10.0 \%$ of victims said it was the first time they had suffered sexual abuse and 10\% had suffered sexual abuse from six to nine times.

According to the diagnosis of injury of elderly women who suffered sexual violence, $40.0 \%$ described the violence as sexual abuse, $10 \%$ as unspecified maltreatment, and 50\% did not provide this information.
Data was not provided regarding the time the violence occurred.

It was also evaluated if the victim had a disability, whether physical, visual or of another type. In the case of sexual violence, all the elderly women had a disability, although which type was not specified. Among the elderly women who suffered physical violence, $1.0 \%$ were physically disabled and $1.0 \%$ had a visual impairment, while the other data were ignored.

Among the victims of physical violence, 3.8\% abused alcohol or drugs. This information was not provided for victims of sexual violence.

Of the cases of elderly women who suffered physical and sexual violence, $57.5 \%$ were immediately discharged from hospital, $0.4 \%$ died in care, $1.3 \%$ were hospitalized and $12.4 \%$ were transferred to another service.

Only $13.7 \%$ of cases of elderly female victims of physical and sexual violence were referred to the Protective Services Authority for the elderly.

\section{DISCUSSION}

Understanding the different manifestations of the types of violence against elderly persons is fundamental for an intervention. In the studied period, 289 cases of physical violence and ten cases of sexual violence were reported. The present study aimed to analyze elderly women who were victims of violence, and this profile of victims is in line 
with international studies that also report the strong genderization of this phenomenon, with more women than men suffering this phenomenon ${ }^{20}$.

Studies have found the family environment to be the main context for the occurrence of violence against elderly women, making this a serious social and public health problem ${ }^{21}$. In the present study, the majority of the physical and sexual violence was committed by relatives or acquaintances and occurred within the victim's own residence.

For a more in-depth analysis of the context of violence, one aspect investigated was the victim and aggressor relationship. Most of the perpetrators were relatives of or were known to the victim. Differences have been found in relation to the gender of the victim, as men were the aggressors in the majority of cases of violence against women ${ }^{22}$. In the present study, $40.1 \%$ of aggressors in physical violence and $50.0 \%$ of aggressors in cases of sexual violence were men.

The predominance of violence in the domestic environment corroborates recent research where violence was more prevalent in the home - a place considered a warm, loving environment which offers protection against external violence. In contrast, the intra-family relationship emerges concomitantly as a source of conflict that exposes elderly women to the risk of violence of a veiled nature by family members, with a high degree of underreporting ${ }^{20,23}$.

The study discusses the process of coping with violence against elderly women from the perspective of services, identifying the need for intersectoral operations and professional training in relation to referrals and notification, so that elderly women can be cared for in an integral manner ${ }^{24}$.

The obligation of health professionals to identify and report violence against elderly women is noted, as this issue has gained momentum in recent research and through the formulation of more effective public policies to guarantee the rights of this age group, especially in the field of health and safety ${ }^{25}$.

It is compulsory that public and private health services notify cases of suspected or confirmed violence committed against the elderly to the health authorities and also to the following services: the police; the Public Prosecutor's Office; the Municipal Council of the Elderly; the State Council for the Elderly and the National Council for the Elderly ${ }^{25}$. In the present study, it was found that only $13.7 \%$ of cases of elderly female victims of physical and sexual violence were referred to the Protective Services Authority for the Elderly.

In many cases underreporting and a lack of monitoring and guidance make it difficult to achieve a continuous, standardized and adequate record of violence. This situation is repeated when the victims of violence are children, women, homosexuals, the elderly, the sick, the poor and the homeless, leading to the interpretation that there are people who are not recognized as citizens and who lack rights ${ }^{26}$.

The compulsory notification of violence against the elderly, which is viewed in a consensual manner in literature, should be considered an instrument of guaranteeing rights and social protection, allowing medical professionals and other health, education and social care professionals, as well as Protective Services Authorities, to adopt suitable measures ${ }^{26}$.

In order to ensure efficient and effective care by the professionals involved in the welfare of elderly female victims of violence at a local level, a policy of institutional responsibility is required to encourage doctors and nurses to perform this notification. A care protocol should also be implemented, clearly defining the role of each member, institution, government body and sector of civil society and those of professionals involved in the care and prevention of violence, so as to build a hierarchical, articulated and continuous network of actions ${ }^{27}$.

The need for specific training of professionals is emphasized, including of doctors who work in health services, so that they can provide care for elderly victims and their families and have the ability and competence to prevent situations of violence and carry out epidemiological research into this subject, which can guide actions relating to the prevention, recognition and confrontation of violence against the elderly ${ }^{28}$. It is important to state that the results of the present study do not provide sufficient support to assess the magnitude of intrafamily violence against elderly women, identify cases of omission of victims and their families, or evaluate whether proper notification is carried out by health services. 
The creation of a culture of acceptance of the aging process as a normal and irreversible stage of human existence is required, in which the elderly have the right to live with dignity and are given opportunities to fully participate in social life without violence ${ }^{28}$.

\section{CONCLUSION}

In the present study, 299 cases of physical and sexual violence against women aged 60 years and older occurred in the city of São Paulo in 2013. During the study period, 289 cases of physical violence and ten cases of physical violence were reported. Much of the physical violence and sexual violence against the elderly woman was committed

\section{REFERENCES}

1. Rocha EN, Vilela ABA, Silva DN. Enfrentamento da violência intrafamiliar contra pessoas idosas pelos profissionais de saúde. Rev Kairós. 2015;18(4):29-46.

2. Reis LA, Gomes NP, Reis LA, Menezes TMO, Carneiro JB. Expressão da violência intrafamiliar contra idosos. Acta Paul Enferm. 2014;27(5):434-9.

3. Paskulin LMG, Valer DB, Vianna LAC. Utilização e acesso de idosos a serviços de atenção básica em Porto Alegre (RS, Brasil). Ciênc Saúde Coletiva. 2011;16(6):2935-44.

4. Rodrigues RAP, Monteiro EA, Santos AMR, Pontes MLF, Fohn JRS, Bolina AF, et al. Violência contra idosos em três municípios brasileiros. Rev Bras Enferm. 2017;70(4):816-24.

5. Silva CFS, Dias CMSB. Violência contra idosos na família: motivações, sentimentos e necessidades do agressor. Psicol Ciênc Profissão. 2016;36(3):637-52.

6. Freitas CASL, Teófilo TJS. Avaliação construtivista, sob uma abordagem integradora e intersetorial, das ações do Projeto Disque Idoso em Sobral (CE, Brasil). Ciênc Saúde Coletiva. 2010;15(6):2825-33.

7. Wanderbroocke ACNS, Moré CLOO. Abordagem profissional da violência familiar contra o idoso em uma unidade básica de saúde. Cad Saúde Pública. 2013;29(12):2513-22.

8. Santana IO, Vasconcelos DC, Coutinho MPL. Prevalência da violência contra o idoso no Brasil: revisão analítica. Arq Bras Psicol. 2016;68(1):126-39. within the family, with the aggressors relatives or known to the victims, and mainly male.

Regarding the care provided to elderly female victims of physical and sexual violence, $57.5 \%$ of cases were immediately discharged from hospital, and only $13.7 \%$ of cases were referred to the Protective Services Authority for the elderly.

Further studies of the issue of violence against the elderly population are needed, with a view to improving care and the completion of the data in the notification form for suspected and confirmed cases of accidents and violence, as well as the implementation of relevant and effective health policies.
9. Faustino AM, Moura LBA, Gandolfi L. Relationship between violence and $\operatorname{cognitive}$ function in the elderly. J Nurs UFPE on line. 2016;10(5):1717-23.

10. Shimbo AY, Labronici LM, Mantovani MF. Reconhecimento da violência intrafamiliar contra idosos pela da Estratégia Saúde da Família. Esc Anna Nery Rev Enferm. 2011;15(3):506-10.

11. Tomimatsu MFAI, Andrade SM, Soares DA, Mathias TAF, Sapata MPM, Soares DFPP, et al. Qualidade da informação sobre causas externas no Sistema de Informações Hospitalares. Rev Saúde Pública. 2009;43(3):413-20.

12. São Paulo. Secretaria Municipal de Saúde, Coordenação de Vigilância em Saúde. Sistema de Informação de Violência e Acidentes - SIVVA: manual de preenchimento ficha de notificação de casos suspeitos ou confirmados. São Paulo: SMS; 2007.

13. São Paulo. Secretaria Municipal de Saúde. Sistema de Informação e Vigilância de Violências e Acidentes SIVVA [Internet]. São Paulo: Prefeitura de São Paulo; 2013 [acesso em 20 jul. 2014]. Disponível em: http:// www.prefeitura.sp.gov.br

14. DATASUS [Internet]. Rio de Janeiro: DATASUS; 1991-. Sistema de Informação Hospitalar SIH [Internet]. 2008 [acesso em 20 jul. 2014]; [aproximadamente 2 telas]. Disponível em: http:// www.prefeitura.sp.gov.br 
15. Facuri CO, Fernandes AMS, Oliveira KD, Andrade TS, Azevedo RCS. Violência sexual: estudo descritivo sobre as vítimas e o atendimento em um serviço universitário de referência no Estado de São Paulo, Brasil. Cad Saúde Pública. 2013;29(5):889-98.

16. Saliba O, Garbin CAS, Garbin AJI, Dossi AP. Responsabilidade do profissional de saúde sobre a notificação de casos de violência doméstica. Rev Saúde Pública. 2007;41(3):472-7.

17. Justo JS, Rozendo AS. A velhice no Estatuto do Idoso. Estud Pesqui Psicol. 2010;10(2):471-89.

18. Mascarenhas MDM, Andrade SSCA, Das Neves ACM, Pedrosa AAG, Da Silva MMA, Malta DC. Violência contra a pessoa idosa: análise das notificações realizadas no setor saúde - Brasil, 2010. Ciênc Saúde Coletiva. 2012;17(9):2331-41.

19. Ribeiro AP, Souza ER, Valadares FC. Atendimento de saúde para pessoas idosas vítimas de violência no município do Rio de Janeiro. Ciênc Saúde Coletiva. 2012;17(5):1164-77.

20. Paiva MM, Tavares DMS. Violência física e psicológica contra idosos: prevalência e fatores associados. Rev Bras Enferm. 2015;68(6):727-33.

21. Rodrigues CL, Armond JE, Górios C. Agressões físicas e sexuais contra idosos notificadas na cidade de São Paulo. Rev Bras Geriatr Gerontol. 2015;18(4):755-60.

Received: July 06, 2016

Reviewed: October 12, 2017

Accepted: November 15, 2017
22. Gil AP, Santos AJ, Kislaya I, Santos C, Mascoli L, Ferreira AI, et al. Estudo sobre pessoas idosas vítimas de violência em Portugal: sociografia da ocorrência. Cad Saúde Pública. 2015;31(6):1234-46.

23. Aguiar MPC, Leite HA, Dias IM, Mattos MCT, Lima WR. Violência contra idosos: descrição de casos no Município de Aracaju, Sergipe, Brasil. Esc Anna Nery Rev Enferm. 2015;19(2):343-9.

24. Menezes PPM, Lima IS, Correia CM, Souza SS, Erdmann AL, Gomes NP. Enfrentamento da violência contra a mulher: articulação intersetorial e atenção integral. Saúde Soc. 2014;23(3):778-86.

25. Sales DS, Freitas CA, Brito MC, Oliveira E, Dias F, Parente F, et al. A violência contra o idoso na visão do agente comunitário de saúde. Estud Interdiscip Envelhec. 2014;19(1):63-77.

26. Garbin CAS, Dias IA, Rovida TAS, Garbin AJI. Desafıos do profissional de saúde na notifıcação da violência: obrigatoriedade, efetivação e encaminhamento. Ciênc Saúde Coletiva. 2015;20(6):1879-90.

27. Thomazine AM, Oliveira BRG, Vieira SC. Atenção a crianças e adolescentes vítimas de violência intrafamiliar por enfermeiros em serviços de pronto-atendimento. Rev Eletrônica Enferm. 2009;11(4):830-40.

28. Alencar KCA, Santos JO, Hino P. Vivência de situação de violência contra idosos. Rev Enferm Atenção Saúde. 2014;3(1):74-83. 